\title{
Testicular Cancer pM1b TNM Finding v7
}

National Cancer Institute

\section{Source}

National Cancer Institute. Testicular Cancer PM1b TNM Finding v7. NCI Thesaurus. Code C89256.

Testicular cancer with metastasis other than to non-regional lymph nodes and lung. (from AJCC 7th Ed.) 